\title{
A Contribution to the Analysis of Recovery Data for the Determination of the Hydraulic Properties of an Aquifer
}

\author{
By \\ Zvonimir Haman and Lars Jørgen Andersen
}

\section{Dansk sammendrag}

Bidrag til analyseringen af stigningsdata for bestemmelsen af de hydrauliske egenskaber $\mathrm{i}$ et grundvandsreservoir

I kommission hos

C. A. REITZELS FORLAG

KØBENHAVN 1970 


\title{
A Contribution to the Analysis of Recovery Data for the Determination of the Hydraulic Properties of an Aquifer
}

\author{
By \\ Zvonimir Haman and Lars Jørgen Andersen
}

\section{Dansk Sammendrag:}

Bidrag til analyseringen af stigningsdata for bestemmelsen af de hydrauliske egenskaber i et grundvandsreservoir 
ISBN 8742106044 


\section{CONTENTS}

Abstract........................... 5

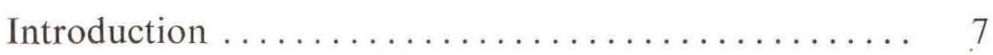

Symbols, Definitions and Units............ 7

Theoretical Statement and Data ............. 8

Terms of Recovery................... 10

1. Residual drawdown, $\mathrm{s}^{\prime}=\mathrm{h}_{0}-\mathrm{h}^{\prime} \ldots \ldots \ldots \ldots \ldots \ldots \ldots \ldots \ldots . \ldots \ldots$

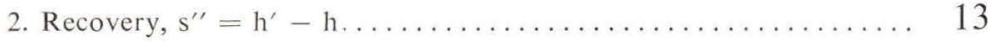

3. Calculation of recovery $\left(\mathrm{s}^{\prime \prime}\right)$ from the extrapolated drawdowns .... 17

Corrections for Barometric Efficiency........... 10

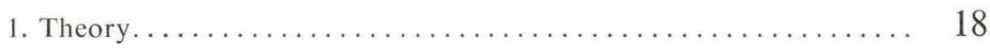

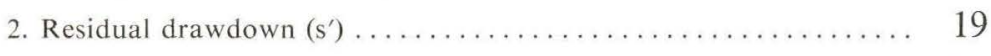

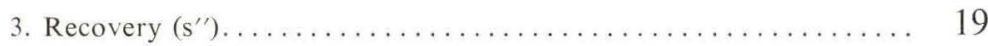

Comparison of Results ................. 21

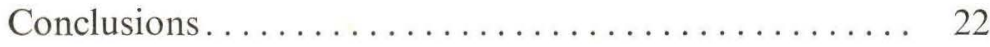

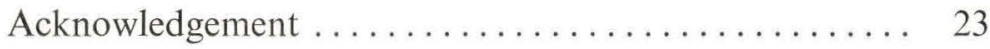

Dansk sammendrag ................... 23

Literature........................ 24 


\begin{abstract}
The purpose of this paper is to present a more reliable calculation of hydraulic properties (T) and (S) utilizing recovery data instead of residual drawdown data. A useful formula for the computation of the recovery from the extrapolated drawdown is recommended. Practical data for this paper has been obtained from a pumping test in an artesian aquifer at Hvinningdal, Silkeborg, Denmark. The calculations are made by means of the nonequilibrium formulas of Theis and Jacob. In addition, the paper provides procedure and examples of adjustments of water-level data for barometric efficiency.
\end{abstract}




\section{INTRODUCTION}

During the last few years the Hydrogeological Department of the Geological Survey of Denmark has introduced practical methods for determination of the hydraulic properties and evaluation of aquifers. To determine these properties, drawdown data from pumping tests ordinarily has been used. However, if irregularities in the pumping rate take place during the drawdown period, the use of such drawdown data will result in incorrect values of the hydraulic properties. In such cases data of the recovery, or the rise of the water level after stop of pumping, will provide more accurate values since recovery data is obviously uninfluenced by the irregularities of the pumping rate. The hydraulic properties, as calculated in this paper, are based on water level data after stop of pumping, recorded both as recovery data and residual drawdown data. However, this paper demonstrates that the use of recovery data will lead to more reliable results concerning both transmissivity and storage coefficients, and that recovery data may be used instead of residual drawdown data for determination of the hydraulic properties of an aquifer.

\section{SYMBOLS, DEFINITIONS AND UNITS}

$s=\left(h_{0}-h\right):$ drawdown is defined as the distance between the static level prior to the test and the water level at the time $(t)$ after start of pumping, in metres $(m)$.

$\Delta s \quad$ : change of the drawdown over one log cycle, in $(m)$.

$s^{\prime}=\left(h_{0}-h^{\prime}\right):$ residual drawdown is defined as the distance between the static level prior to the test and the water level at the time $\left(t^{\prime}\right)$ after stop of pumping, in $(m)$.

$s^{\prime \prime}=\left(h^{\prime}-h\right)=\left(s-s^{\prime}\right)$ : recovery is defined as the distance between the water level at the time ( $t$ ) after start of pumping, and the water level at the time $\left(t^{\prime}\right)$ after stop of pumping, both referred to the static level prior to the test, in $(m)$.

$t \quad$ : time after start of pumping, in minutes.

$t^{\prime} \quad$ : time after stop of pumping, in minutes.

$t_{0} \quad$ : intersection on the $s=0$ drawdown axis, for semilogarithmic drawdown data plot, in minutes.

$t^{\prime}{ }_{0} \quad$ : intersection on the $s^{\prime \prime}=0$ drawdown axis, for semilogarithmic plot of the recovery data $\left(s^{\prime \prime}\right)$, in minutes.

$\left(t / t^{\prime}\right)_{0}$ : intersection on the $s^{\prime}=0$ drawdown axis, for either semilogarithmic or linear plot of the residual drawdown $\left(s^{\prime}\right)$ data for the ratio $\log \left(t / t^{\prime}\right)$.

$t_{m} \quad:$ an arbitrarily selected value of $(t)$ on the semilogarithmic plot for determination of $S$ coefficient without extrapolation, in minutes.

$h_{0} \quad$ : head before start of pumping, in $(m)$.

$h \quad$ : head during the pumping period, in $(m)$. 
$h^{\prime} \quad$ : head during the recovery period, in $(m)$.

$r \quad:$ distance from the pumping well to the observation point, in $(m)$.

$Q \quad$ : discharge of the pumping well, in $\left(\mathrm{m}^{3} / \mathrm{sec}\right.$.).

$c \quad:$ Wenzel's correction for the residual drawdown $\left(s^{\prime}\right)$, in minutes.

$\Delta W$ : change in the water level, in $(\mathrm{cm})$, during drawdown period, due to air pressure change.

$\Delta W^{\prime}$ : change in the water level, in (cm), during recovery period, due to air pressure change.

$\Delta P \quad$ : change in the atmospheric pressure in $(\mathrm{mm})$ of the mercury column during the drawdown period (multiplied with 1,36 and expressed as $(\mathrm{cm})$ of water column).

$\Delta P^{\prime} \quad$ : change in the atmospheric pressure in $(\mathrm{mm})$ of mercury column during the recovery period (multiplied with 1,36 and expressed as (cm) of water column).

$B E$ : barometric efficiency, in per cent.

$T \quad$ : coefficient of transmissivity, in ( $\mathrm{m}^{2} / \mathrm{sec}$.), for the drawdown data $(\mathrm{s})$.

$S \quad$ : coefficient of storage for the drawdown data $(s)$.

$S^{\prime} \quad$ : coefficient of storage for the recovery data $\left(s^{\prime}\right),\left(s^{\prime \prime}\right)$.

$W(u)$ : well function of $(u)$ for $\left(u=\frac{r^{2} S}{4 T t}\right)$, during the drawdown period.

$W\left(u^{\prime}\right)$ : well function of $\left(u^{\prime}\right)$ for $\left(u^{\prime}=\frac{r^{2} S^{\prime}}{4 T t^{\prime}}\right)$, during the recovery period.

\section{THEORETICAL STATEMENT AND DATA}

"The non-equilibrium equation is applicable for analysis of the recovery of a pumped well. If a well is pumped for a known period of time and then shut down, the drawdown thereafter will be identically the same as if the discharge had been continued and a recharge well with the same flow were superposed on the discharged well at the instant the discharge well is shut down" (THEIS, C. V. 1935).

The drawdown during the pumping period is defined as:

$$
s=h_{0}-h,
$$

or using the non-equilibrium formulas in units as defined above:

$$
\begin{aligned}
& s=\frac{7,95 \times 10^{-2} Q}{T} W(u),(m) \\
& u=\frac{r^{2} S}{240 T t}, \\
& s=\frac{0,183 Q}{T} \log _{10} \frac{135 T t}{r^{2} S},(m)
\end{aligned}
$$


TABLE 1.

PUMPING TEST DATA $27 / 3$ - 31/3 1969 FROM THE OBSERVATION WELL D.G.U. FILE NO. 87.551 IN AN ARTESIAN AQUIFER HVINNINGDAL - SILKEBORG - DENMARK

DRAWDOWN DATA $\begin{aligned} & \mathrm{Q}=2,43 \times 10^{-2} \mathrm{~m}^{3} / \mathrm{sec} \\ & \mathrm{BE}=30 \%\end{aligned}$

RECOVERY DATA

\begin{tabular}{|c|c|c|c|c|c|c|c|c|c|c|c|c|c|c|c|c|c|c|c|c|}
\hline Date & hour & \begin{tabular}{|l|} 
Time \\
in min \\
$\mathrm{t}$
\end{tabular} & $\begin{array}{l}\Delta \mathrm{P} \\
\mathrm{mm}\end{array}$ & $\begin{array}{l}\Delta W \\
(\mathrm{~m})\end{array}$ & $\begin{array}{c}\mathrm{s} \\
(\mathrm{m})\end{array}$ & $\begin{array}{l}\text { s for } \\
\text { BE } \\
(\mathrm{m})\end{array}$ & Date & Hour & $\begin{array}{l}\text { Time } \\
\text { in } \mathrm{m}_{1 \mathrm{n}} \\
\mathrm{t}^{+}\end{array}$ & $\begin{array}{l}\left(t+t^{\prime}\right) \\
\text { in } m i n\end{array}$ & $t / t^{\prime}$ & $\begin{array}{l}\log \\
t / t\end{array}$ & $\frac{t-2490}{t^{\prime}}$ & $\log \frac{t-2490}{t}$ & \begin{tabular}{|l|l|}
0 & $\begin{array}{l}\Delta \mathrm{P}^{\prime} \\
\mathrm{mm}\end{array}$
\end{tabular} & \begin{tabular}{|l}
$\Delta W$ \\
$(\mathrm{~m})$
\end{tabular} & $\begin{array}{l}S^{\prime} \\
(m)\end{array}$ & 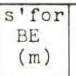 & $\begin{array}{l}s^{\prime \prime} \\
(m)\end{array}$ & $\begin{array}{l}s^{\prime \prime f o r ~} \\
\text { BE } \\
\text { (m) }\end{array}$ \\
\hline \multirow[t]{24}{*}{$27 / 3$} & & 0 & & & 0 & & & & & & & & & & & & & & & \\
\hline & $14^{00}$ & 0 & 0 & 0 & 0 & & $29 / 3$ & $11^{00}$ & & & & & & & & & & & & \\
\hline & & 3,75 & 0 & 0 & 0,37 & 0,37 & & & 7 & 2707 & 386 & 2,596 & 3,11 & 1,489 & & & 0,585 & 0,585 & 0,44 & 0,46 \\
\hline & & 7,5 & 0 & 0 & 0,51 & 0,51 & & & 14,5 & 2714,5 & 187 & 2,272 & 15,5 & 1,19 & & & 0,435 & 0,435 & 0,59 & 0,61 \\
\hline & & 11,25 & 0 & 0 & 0,57 & 0,57 & & & 22 & 2722 & 124 & 2,094 & 10,55 & 1,023 & & & 0,373 & 0,373 & 0,652 & 0,672 \\
\hline & & 15 & 0 & 0 & 0,615 & 0,615 & & & 29,5 & 2729,5 & 92,6 & 1,967 & 8,92 & 0,95 & & & 0,345 & 0,345 & 0,68 & 0,70 \\
\hline & & 18,75 & 0 & 0 & 0,645 & 0,645 & & & 37,0 & 2737 & 73,9 & 1,368 & 6,68 & 0,825 & $-0,2$ & 0,001 & 0,31 & 0,311 & 0,715 & 0,734 \\
\hline & & 22,5 & 0 & 0 & 0,665 & 0,665 & & & 44,5 & 2744,5 & 67,9 & 1,831 & 5,73 & 0,758 & $-0,3$ & 0,001 & 0,285 & 0,286 & 0,74 & 0,759 \\
\hline & & 30 & 0 & 0 & 0,70 & 0,70 & & & 52 & 2752 & 53,0 & 1,724 & 5,03 & 0,702 & $-0,3$ & 0,001 & 0,27 & $0,271$. & 0,755 & 0,774 \\
\hline & & 33 & 0 & 0 & 0,71 & 0,71 & & & 60 & 2760 & 46,0 & 1,663 & 4,5 & 0,654 & $-0,3$ & 0,001 & 0,255 & 0,256 & 0,77 & 0,789 \\
\hline & & 45 & 0 & 0 & 0,75 & 0,75 & & & 75 & 2775 & 37,0 & 1,568 & 3,8 & 0,58 & $-0,4$ & 0,002 & 0,23 & 0,232 & 0,795 & 0,813 \\
\hline & & 60 & $-0,2$ & 0,001 & 0,78 & 0,781 & & & 90 & 2790 & 31,0 & 1,502 & 3,34 & 0,522 & $-0,4$ & 0,002 & 0,21 & 0,212 & 0,815 & 0,833 \\
\hline & & 75 & $-0,2$ & 0,001 & 0,80 & 0,801 & & & 120 & 2820 & 23,5 & 1,371 & 2,66 & 0,426 & $-0,4$ & 0,002 & 0,18 & 0,02 & 0,845 & 0,863 \\
\hline & & 90 & $-0,2$ & 0,001 & 0,825 & 0,826 & & & 150 & 2850 & 19,0 & 1,278 & 2,4 & 0,38 & $-0,8$ & 0,003 & 0,152 & 0,155 & 0,873 & 0,890 \\
\hline & & 120 & $-0,2$ & 0,001 & 0,855 & 0,856 & & & 180 & 2880 & 16,0 & 1,204 & 2,16 & 0,336 & $-1,1$ & 0,004 & 0,135 & 0,139 & 0,89 & 0,906 \\
\hline & & 150 & $-0,2$ & 0,001 & 0,88 & 0,881 & & & 240 & 2940 & 12,7 & 1,104 & 1,88 & 0,274 & $-1,3$ & 0,005 & 0,108 & 0,113 & 0,917 & 0,932 \\
\hline & & 180 & $-0,4$ & 0,002 & 0,895 & 0,897 & & & 300 & 3000 & 10,0 & 1,00 & 1,70 & 0,23 & $-1,6$ & 0,007 & 0,088 & 0,095 & 0,937 & 0,950 \\
\hline & & 195 & $-0,4$ & 0,002 & 0,91 & 0,912 & & & 420 & 3120 & 7,44 & 0,871 & 1,5 & 0,176 & $-0,4$ & 0,01 & 0,060 & 0,07 & 0,965 & 0,975 \\
\hline & & 200 & 0 & 0 & 0,91 & 0,91 & & & 540 & 3240 & 6,0 & 0,778 & 1,39 & 0,42 & $-2,9$ & 0,012 & 0,045 & 0,057 & 0,98 & 0,988 \\
\hline & & 240 & 0 & 0 & 0,925 & 0,925 & $30 / 3$ & & 780 & 3480 & 4,47 & 0,65 & 1,27 & 0,104 & $-5,1$ & 0,021 & 0,022 & 0,043 & 1,003 & 1,002 \\
\hline & & 300 & 0 & 0 & 0,95 & 0,95 & & & 1020 & 3840 & 4,15 & 0,618 & 1,21 & 0,081 & $-8,5$ & 0,035 & 0,004 & 0,039 & 1,021 & 1,006 \\
\hline & & 420 & 0 & 0 & 0,975 & 0,975 & & & 1380 & 4200 & 3,04 & 0,483 & 1,15 & 0,062 & $-13,1$ & $0,055+$ & $+0,015$ & 0,040 & 1,040 & 1,005 \\
\hline & & 480 & $+0,2$ & 0,001 & 0,985 & 0,984 & & & 1740 & 4560 & 2,62 & 0,428 & 1,12 & 0,05 & $-17,0$ & $0,070+$ & $+0,034$ & 0,036 & 1,059 & 1,009 \\
\hline & & 600 & $+0,2$ & 0,001 & 0,995 & 0,994 & & & 2100 & 4720 & 2,24 & 0,35 & 1,09 & 0,04 & $-17,2$ & $0,071+$ & $+0,035$ & 0,036 & 1,060 & 1,009 \\
\hline \multirow[t]{4}{*}{$28 / 3$} & & 960 & $+0,3$ & 0,001 & 1,915 & 1,014 & $31 / 3$ & & 2460 & 5280 & 2,14 & 0,33 & 1,085 & 0,035 & $-17,3$ & $0,071+$ & $+0,031$ & 0,040 & 1,056 & 1,005 \\
\hline & & 1320 & $+0,4$ & 0,001 & 1,02 & 1,018 & & & 2820 & 5640 & 2,0 & 0,302 & 1,075 & 0,031 & $-17,5$ & $\mid 0,072$ & $+0,030$ & 0,042 & 1,055 & 1,003 \\
\hline & & 1364 & $+0,4$ & 0,002 & 1,02 & 1,018 & & & & & & & & & & & & & & \\
\hline & & 1680 & $-0,5$ & 0,002 & 1,025 & 1,027 & & & & & & & & & & & & & & \\
\hline \multirow[t]{4}{*}{$29 / 3$} & & 2040 & $-0,9$ & 0,004 & 1,03 & 1,034 & & & & & & & & & & & & & & \\
\hline & & 2400 & $-3,1$ & 0,013 & 1,025 & 1,038 & & & & & & & & & & & & & & \\
\hline & & 2687 & $-4,7$ & 0,019 & 1,025 & 1,044 & & & & & & & & & & & & & & \\
\hline & & 2700 & $-4,8$ & 0,02 & 1,025 & 1,045 & & & & & & & & & & & & & & \\
\hline
\end{tabular}


From Table 1, drawdown data are plotted in Fig. 2, and the coefficients (T) and $(S)$ are calculated (see Table 2), and later used for the comparison with the $T$ and $S$ coefficients calculated on base of the different terms of recovery data. When the pump is shut down, the recovery of the head $\left(h^{\prime}\right)$ begins and lasts until $\left(h_{0}=h^{\prime}\right)$, that is, until the static level prior to the pumping test is reached.

\section{TERMS OF RECOVERY}

The values which represent recovery of the water level, according to different authors, can be recorded as follows:

1. RESIDUAL DRAWDOWN, $\mathrm{s}^{\prime}=\left(\mathrm{h}_{0}-\mathrm{h}^{\prime}\right)$

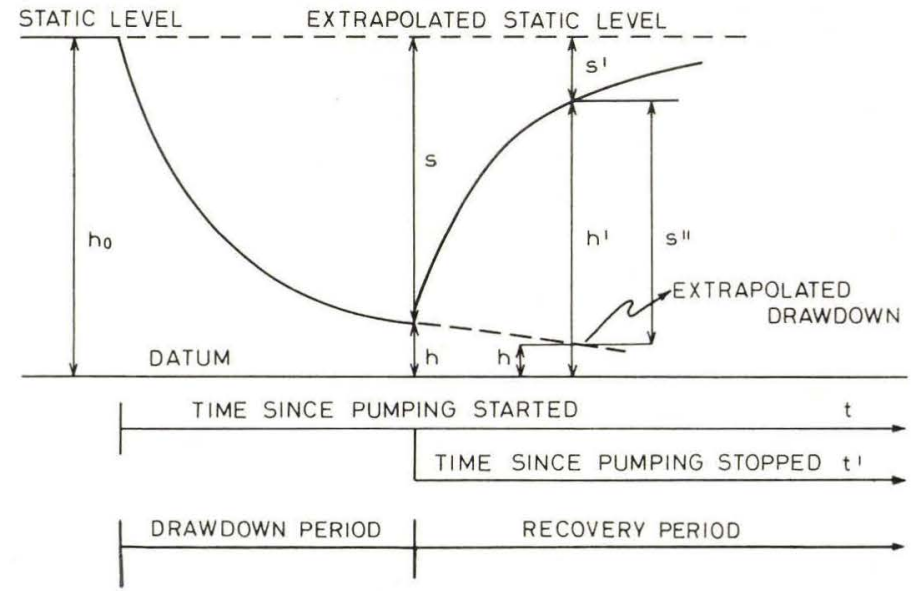

Fig. 1. Sketch of drawdown, residual drawdown ( $\left.\mathrm{s}^{\prime}\right)$ and recovery (s") of water level

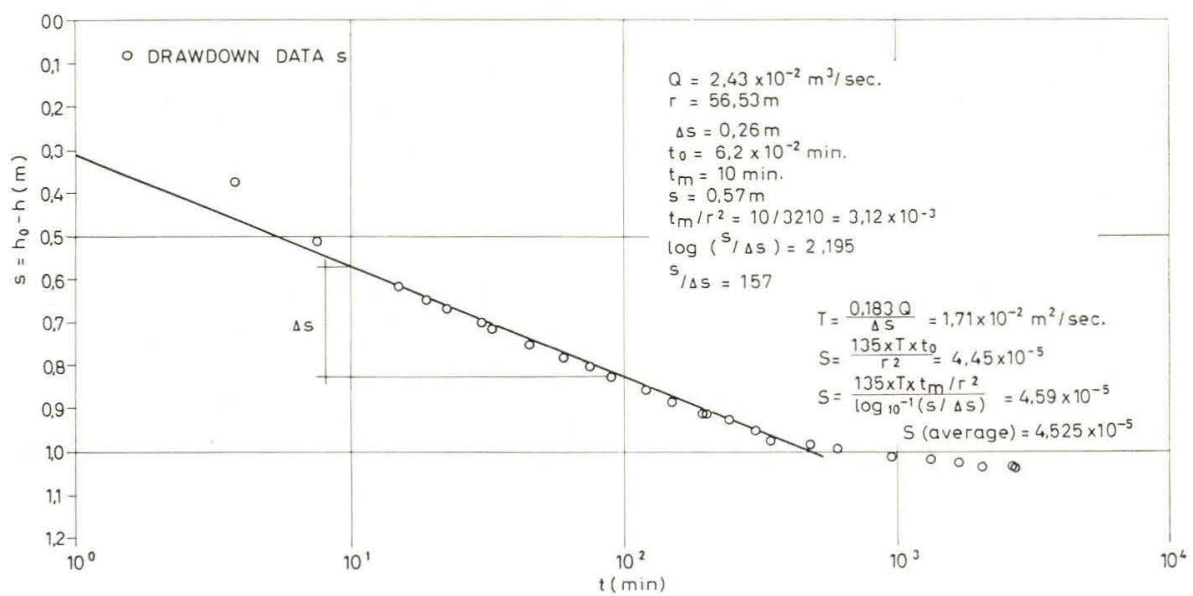

Fig. 2. Semilogarithmic plot of drawdown data (s) 
According to the Fig. 1 it is possible to state:

$$
\begin{aligned}
& s=\left(h_{0}-h\right), \\
& s^{\prime}=\left(h_{0}-h^{\prime}\right), \\
& s^{\prime \prime}=\left(s-s^{\prime}\right)=\left(h_{0}-h\right)-\left(h_{0}-h^{\prime}\right)=\left(h^{\prime}-h\right), \\
& s^{\prime}=\left(s-s^{\prime \prime}\right)=\left(h_{0}-h\right)-\left(h^{\prime}-h\right)=\left(h_{0}-h^{\prime}\right),
\end{aligned}
$$

Value of the residual drawdown $\left(s^{\prime}\right)$ is the distance between the static level prior to the test and the water level at the time $t^{\prime}$ after stop of pumping. By using the modified non-equilibrium formula:

$$
s^{\prime}=\frac{2,30 Q}{4 \pi T}\left[\log _{10}\left(\frac{2,25 T t}{r^{2} S}\right)-\log _{10}\left(\frac{2,25 T t^{\prime}}{r^{2} S^{\prime}}\right)\right]
$$

and in units as defined above:

$$
s^{\prime}=\frac{0,183 Q}{T}\left[\log _{10}\left(\frac{t}{S}\right)-\log _{10}\left(\frac{t^{\prime}}{S^{\prime}}\right)\right],(m)
$$

from which solution for $T$ is obtained.

To obtain solution for $S^{\prime}$ let $s^{\prime}=0$ then

$$
\begin{aligned}
\log _{10}\left(\frac{t S^{\prime}}{t^{\prime} S}\right) & =0 \\
\frac{t S^{\prime}}{t^{\prime} S} & =1
\end{aligned}
$$

and finally

$$
t / t^{\prime}=S / S^{\prime}
$$

Depending on the intersection $\left(t / t^{\prime}\right)$ on the drawdon axis $\left(s^{\prime}=0\right)$, relations between the storage coefficients from drawdown data and residual drawdown $\left(s^{\prime}\right)$ data are as follows:

$$
\begin{array}{ll}
\left(t / t^{\prime}\right)_{0}>1 & S^{\prime}<S \\
\left(t / t^{\prime}\right)_{0}=1 & S^{\prime}=S \\
\left(t / t^{\prime}\right)_{0}<1 & S^{\prime}>S
\end{array}
$$

Equations (7) and (8) are straight line equations of the residual drawdown $\left(s^{\prime}\right)$ plotted against $\log \left(t / t^{\prime}\right)$ on linear paper or $\left(t / t^{\prime}\right)$ on semilogarithmic paper. The plotted data of the residual drawdown $\left(s^{\prime}\right)$ will produce a straight line when sufficient time $\left(t^{\prime}\right)$ has elapsed after stop of pumping. Data from Table 1 are plotted on linear and semilogarithmic paper (Figs. 3 and 4), and the coefficient $T$ is determined by means of the modified non-equilibrium formula:

$$
T=\frac{0,183 Q}{\Delta s^{\prime}} \log \left(t / t^{\prime}\right),\left(m^{2} / \mathrm{sec} .\right)
$$




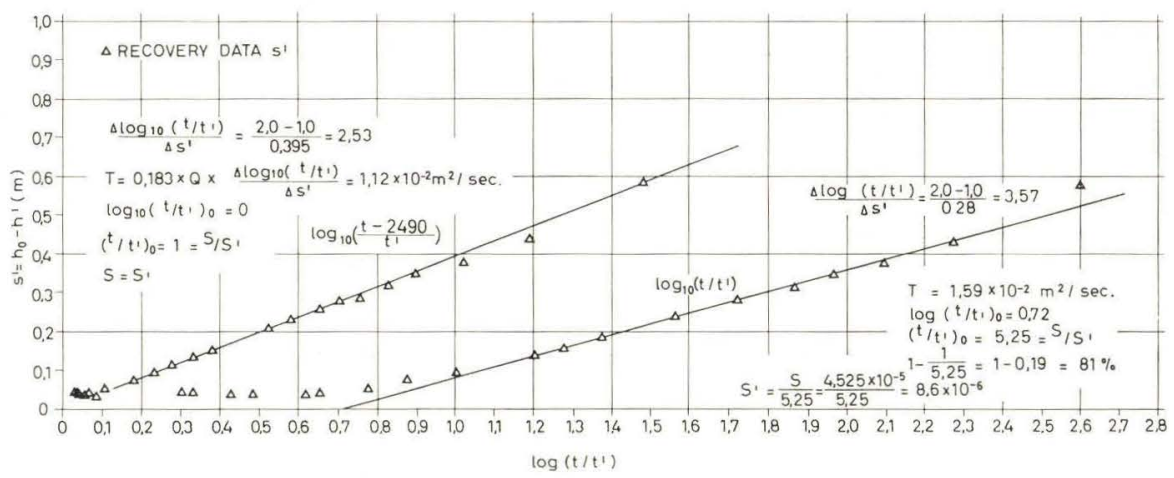

Fig. 3. Arithmetic plot of residual drawdown data (s')

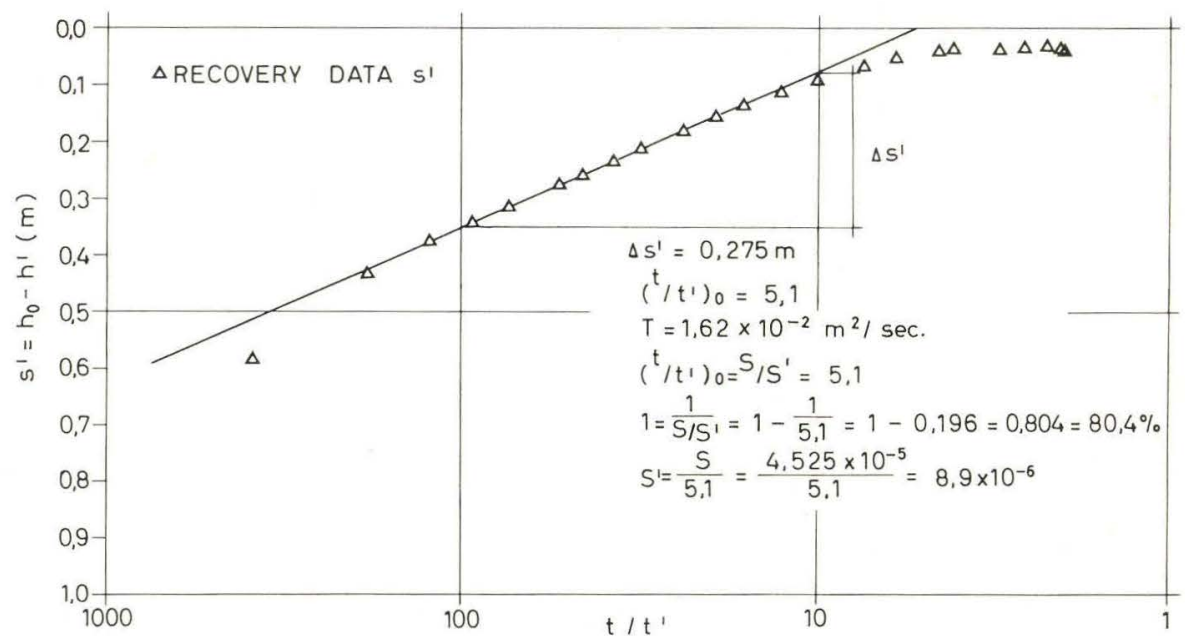

Fig. 4. Semilogarithmic plot of residual drawdown data (s')

as $T=1,59 \times 10^{-2} \mathrm{~m}^{2} / \mathrm{sec} . \quad$ from the linear plot $s^{\prime} v . \log \left(t / t^{\prime}\right)$

$T=1,62 \times 10^{-2} \mathrm{~m}^{2} / \mathrm{sec} . \quad$ from the semilog plot $s^{\prime} v .\left(t / t^{\prime}\right)$.

The coefficient of storage $S^{\prime}$ can be determined from the value of the intersection of the $\left(t / t^{\prime}\right)$ on the drawdown axis $s^{\prime}=0$, and by means of the equation (8):

$$
\left(t / t^{\prime}\right)_{0}=S / S^{\prime}=5,25
$$

The relative change between the storage coefficients from the drawdown data and residual drawdown $\left(s^{\prime}\right)$ data is determined by the formula:

$$
1=\frac{1}{S / S^{\prime}}=1-\frac{1}{S / S^{\prime}}=1-0,19=0,81=81 \text { per cent }
$$


The coefficient $S^{\prime}$ from the residual drawdown data $\left(s^{\prime}\right)$ is:

$$
S^{\prime}=\frac{S}{S / S^{\prime}}=\frac{4,525 \times 10^{-5}}{5,25}=8,6 \times 10^{-6}
$$

where $S$ is calculated from drawdown data (Fig. 2).

The straight line, drawn through the points on the Figs. 3 and 4, intersects $s^{\prime}=0$ on the drawdown axis $\left(t / t^{\prime}\right)_{0}=5,25$ and therefore $S^{\prime}<S$.

According to WeNZEL, (1936), and applying the correction factor $c=2490$ min., the straight line constructed from the values:

$$
\log _{10}\left(\frac{t-2490}{t^{\prime}}\right)
$$

passes through the origin, and $T$ is determined as:

$$
\begin{aligned}
& T=0,183 Q \times\left[\frac{\log _{10}\left(\frac{t-2490}{t^{\prime}}\right)}{\Delta s^{\prime}}\right],\left(\mathrm{m}^{2} / \mathrm{sec} .\right) \\
& T=0,183 \times 2,43 \times 10^{-2} \times 2,53=1,12 \times 10^{-2}\left(\mathrm{~m}^{2} / \mathrm{sec} .\right)
\end{aligned}
$$

In this case $\log _{10}\left(\frac{t-2490}{t^{\prime}}\right)_{0}$ intersects $s^{\prime}=0$ drawdown at the zero value therefore:

$$
\frac{t-2490}{t^{\prime}}=S / S^{\prime}
$$

thus: $S=S^{\prime}$.

By insisting that the straight line should pass through the origin, we equalize storage coefficients from the drawdown data, and residual drawdown data $\left(s^{\prime}\right)$. This is essentially an artificial correspondance, and the consequences will be discussed later.

2. RECOVERY, $\mathrm{s}^{\prime \prime}=\left(\mathrm{h}^{\prime}-\mathrm{h}\right)$

From Fig. 1 it is possible to state:

$$
\begin{aligned}
& s^{\prime \prime}=\left(s-s^{\prime}\right), \\
& s^{\prime \prime}=\left(h_{0}-h\right)-\left(h_{0}-h^{\prime}\right)=\left(h^{\prime}-h\right) .
\end{aligned}
$$

The value of the recovery $\left(s^{\prime \prime}\right)$ is defined as the distance between the water level at the time $(t)$ after start of pumping, and the water level at the time $\left(t^{\prime}\right)$ after stop of pumping, both referred to the static level prior to the test. From Fig. 1 it is also possible to state the recovery $\left(s^{\prime \prime}\right)$ as follows:

$$
s^{\prime \prime}=s-\left(s-s^{\prime \prime}\right),
$$

or using the modified non-equilibrium equation:

$$
s^{\prime \prime}=\left[\left(\frac{2,30 Q}{4 \pi T}\right) \log _{10}\left(\frac{2,25 T t}{r^{2} S}\right)\right]-\frac{2,30 Q}{4 \pi T} \log _{10}\left[\left(\frac{2,25 T t}{r^{2} S}\right)-\log _{10}\left(\frac{2,25 T t^{\prime}}{r^{2} S^{\prime}}\right)\right]
$$


and in units as previously defined

$$
s^{\prime \prime}=\frac{0,183}{T} \underline{Q} \log _{10}\left(\frac{135 T t^{\prime}}{r^{2} S^{\prime}}\right),\left(\mathrm{m}^{2} / \mathrm{sec} .\right)
$$

from which the solution for $T$ is obtained.

To obtain the solution for $S^{\prime}$ let $s^{\prime \prime}=0$.

Then

$$
\log _{10}\left(\frac{135 T t^{\prime}}{r^{2} S^{\prime}}\right)=0
$$

and finally

$$
\frac{135 T t^{\prime}}{r^{2} S^{\prime}}=1
$$

from which the solution for $S^{\prime}$ is obtained.

Depending on the ratio $\left(t_{0} / t^{\prime}{ }_{0}\right)$ the relation between the storage coefficients from the drawndown data and the recovery data $\left(s^{\prime \prime}\right)$ is as follows:

Thus

$$
\begin{array}{ll}
t_{0} / t^{\prime}{ }_{0}=1 & S=S^{\prime} \\
t_{0} / t^{\prime}{ }_{0}>1 & S>S^{\prime} \\
t_{0} / t^{\prime}{ }_{0}<1 & S<S^{\prime}
\end{array}
$$

Values of the recovery data $\left(s^{\prime \prime}\right)$ plotted against $\left(t^{\prime}\right)$ on semilogarithmic paper will produce the straight line, defined with equations (9) and (10), when sufficient time $\left(t^{\prime}\right)$ has elapsed since the stop of pumping.

Data from Table 1 are plotted on semilogarithmic paper (Fig. 5), and values of $T$ and $S^{\prime}$ are determined by means of the modified non-equilibrium equations:

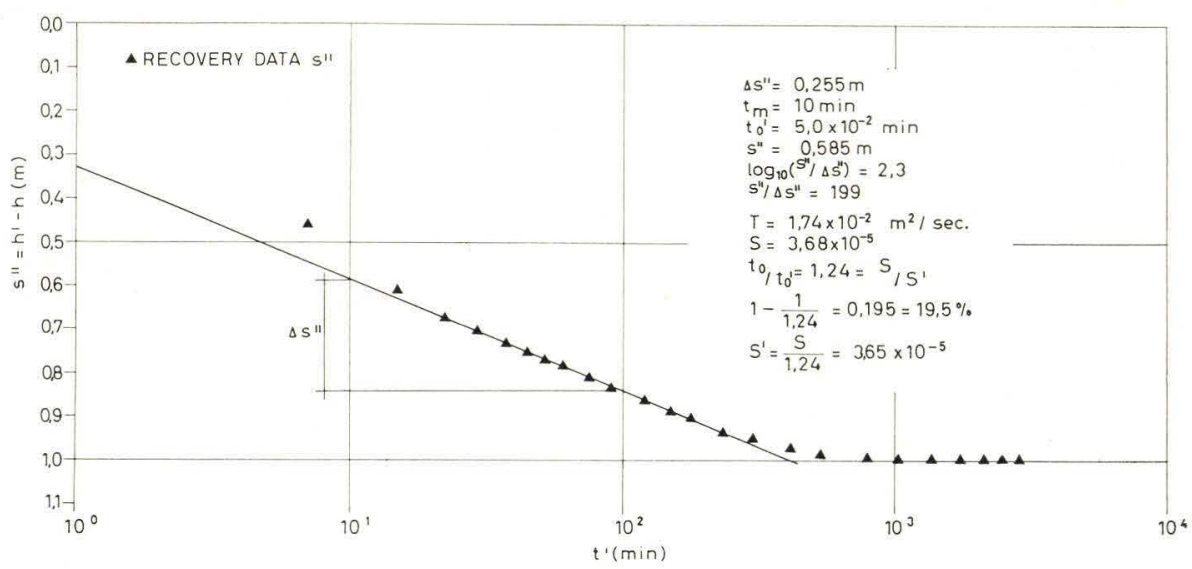

Fig. 5. Semilogarithmic plot of recovery data $\left(\mathrm{s}^{\prime \prime}\right)$ 
and

$$
T=\frac{0,183 Q}{\Delta s^{\prime \prime}}=1,74 \times 10^{-2}\left(\mathrm{~m}^{2} / \mathrm{sec} .\right)
$$

$$
S^{\prime}=\frac{135 T t^{\prime}}{r^{2}}=3,68 \times 10^{-5} \text { without extrapolation of }\left(t^{\prime}{ }_{0}\right)
$$

intersection on the drawdown axis $s^{\prime \prime}=0$.

Intersection $\quad t^{\prime}{ }_{0}=5,0 \times 10^{-2}$ gives $S^{\prime}=3,66 \times 10^{-5}$

The ratio of $t_{0}=6,2 \times 10^{-2}$ and $t^{\prime}{ }_{0}=5,0 \times 10^{-2}$ is

$$
t_{0} / t^{\prime}=1,24 \text {, therefore } S>S^{\prime}
$$

The relative change between the storage coefficients from the drawdown data and the recovery $\left(s^{\prime \prime}\right)$ data is:

$$
1=\frac{1}{S / S^{\prime}}=1-\frac{1}{1,24}=0,195=19,5 \text { per cent. }
$$

If the coefficient $S$ from the drawdown data is $4,525 \times 10^{-5}$, then $S^{\prime}$ from the recovery data $\left(\mathrm{s}^{\prime \prime}\right)$ is calculated:

$$
S^{\prime}=\frac{S}{S / S^{\prime}}=\frac{4,525 \times 10^{-5}}{1,24}=3,65 \times 10^{-5}
$$

If the average value of $S^{\prime}=3,66 \times 10^{-5}$ is adopted, then

$$
S^{\prime} / S=\frac{3,66 \times 10^{-5}}{4,525 \times 10^{-5}}=0,81 .
$$

Thus the relative change between the storage coefficients from recovery data $\left(s^{\prime \prime}\right)$ and drawdown data is 19 per cent.

In the example shown here $s^{\prime \prime}$ is equal to the distance between the drawdown at the end of the pumping period, and to the water level at the required time $\left(t^{\prime}\right)$ since stop of pumping.

From the analysis of the drawdown data it was observed, that no appreciable drawdown would appear if the pumping had been continued, therefore the total drawdown was selected as the level of reference.

The recovery data $\left(s^{\prime \prime}\right)$ can also be analysed by the Theis type curve method. In this case the $\left(s^{\prime \prime}\right)$ values are plotted against $\left(t^{\prime}\right)$ on the logarithmic paper. By the superposition of the type curve $W(u)$ of $(u)$ or $(1 / u)$ over the plotted data, the match point is selected and coordinates of $\left(s^{\prime \prime}\right),\left(t^{\prime}\right),(u)$, or $(1 / u)$ and $W(u)$ are noted.

By means of the Theis non-equilibrium formula $T$ and $S^{\prime}$ can be calculated as follows:

As can be seen from Fig. 1

or

$$
\begin{aligned}
& s^{\prime \prime}=\left(s-s^{\prime}\right), \\
& s^{\prime \prime}=s-\left(s-s^{\prime \prime}\right),
\end{aligned}
$$


and using Theis non-equilibrium formula

$$
s^{\prime \prime}=\frac{Q}{4 \pi T} W(u)-\left[\frac{Q}{4 \pi T} W(u)-\frac{Q}{4 \pi T} W\left(u^{\prime}\right)\right],
$$

or in units as previously defined

$$
\begin{aligned}
s^{\prime \prime} & =\frac{7,95 \times 10^{-2} Q}{T} W\left(u^{\prime}\right),\left(\mathrm{m}^{2} / \mathrm{sec} .\right) \\
u^{\prime} & =\frac{r^{2} S^{\prime}}{240 T t^{\prime}},
\end{aligned}
$$

from which solutions for $T$ and $S^{\prime}$ are obtained.

Data from Table 1 are plotted on the logarithmic paper (Fig. 6). By superposition of the type curve over data curve, the match point with following coordinates is selected.

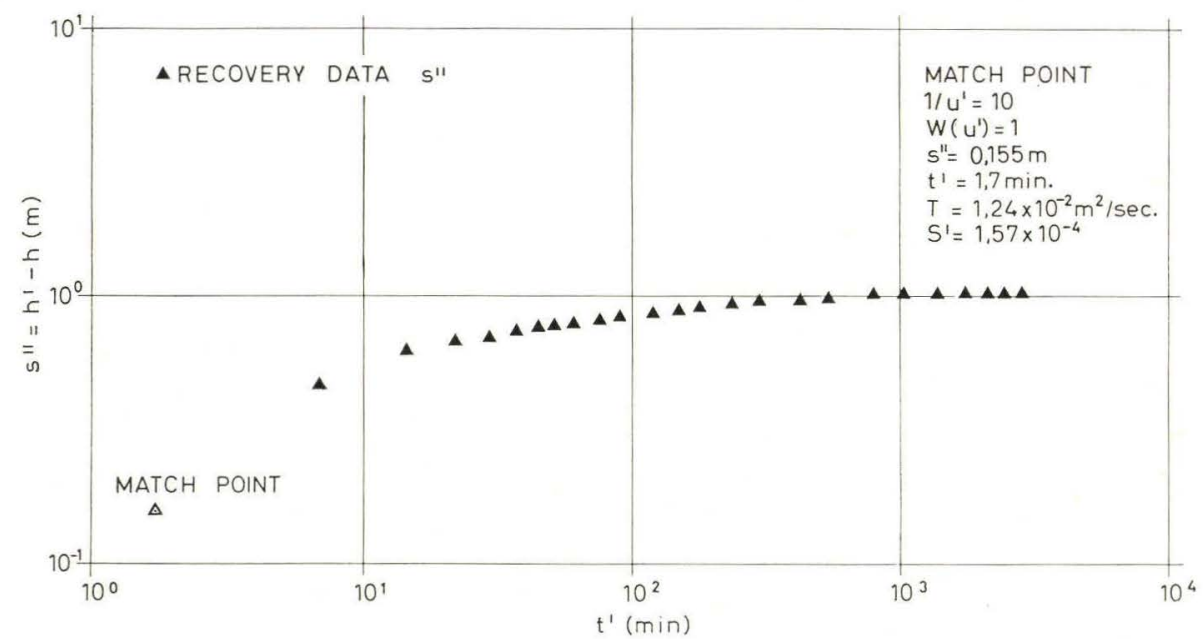

Fig. 6. Logarithmic plot of recovery data $\left(s^{\prime \prime}\right)$

$$
\begin{aligned}
& 1 / u^{\prime}=10 \\
& W\left(u^{\prime}\right)=1 \\
& s^{\prime \prime}=0,155 \mathrm{~m} \\
& t^{\prime}=1,7 \mathrm{~min} . \\
& T=\frac{7,95 \times 10^{-2}}{s^{\prime \prime}} W\left(u^{\prime}\right)=1,24 \times 10^{-2}\left(\mathrm{~m}^{2} / \mathrm{sec} .\right) \\
& S^{\prime}=\frac{240 T t^{\prime}}{r^{2}}=1,57 \times 10^{-4}
\end{aligned}
$$


From the drawdown data Table 1 and Fig. $7 T$ and $S$ values are determined, by means of the Theis type curve method, and by match point coordinates as:

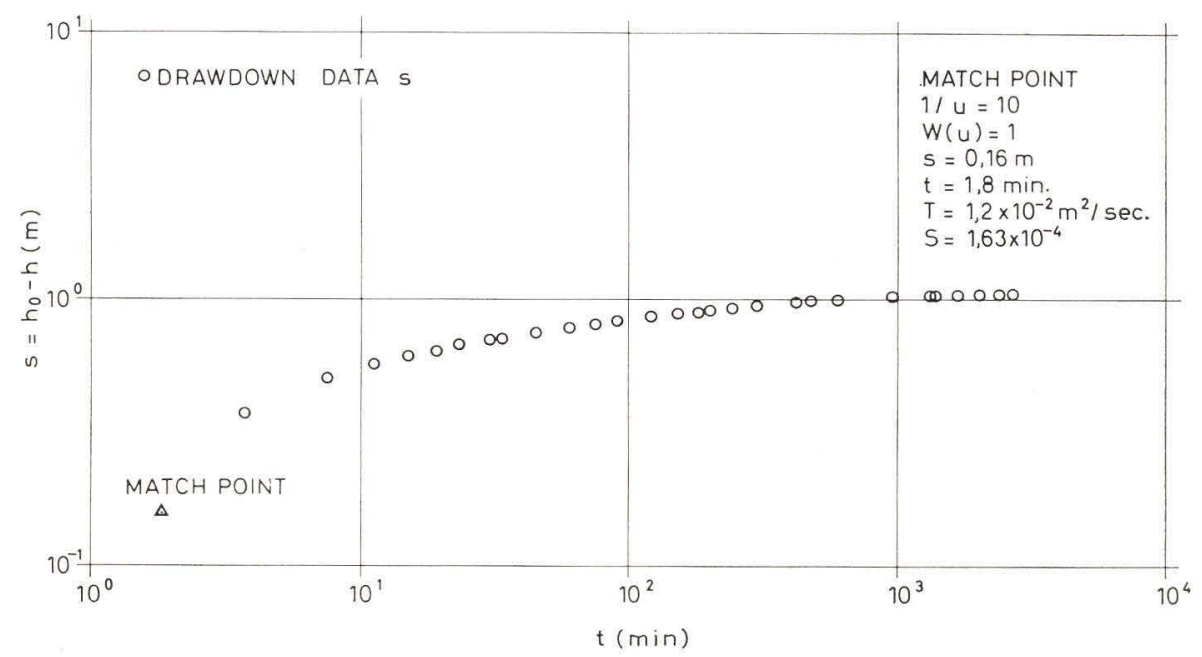

Fig. 7. Logarithmic plot of drawdon data (s)

$$
\begin{aligned}
& 1 / u=10 \\
& W(u)=1 \\
& s \quad=0,16 \mathrm{~m} \\
& t \quad=1,8 \mathrm{~min} . \\
& T \quad=1,2 \times 10^{-2}\left(\mathrm{~m}^{2} / \mathrm{sec} .\right) \\
& S \quad=1,63 \times 10^{-4}
\end{aligned}
$$

The ratio between the storage coefficients from recovery $\left(s^{\prime \prime}\right)$ data and drawdown is:

$$
S^{\prime} / S=\frac{1,57 \times 10^{-4}}{1,63 \times 10^{-4}}=0,964
$$

or the relative change is 3,6 per cent and therefore $S>S^{\prime}$.

\section{CALCULATION OF THE RECOVERY ( $\left.\mathrm{s}^{\prime \prime}\right)$ FROM THE EXTRAPOLATED DRAWDOWNS}

If the data show an increase of the drawdown when pumping continues, then for the required time $\left(t^{\prime}\right)$ it is necessary to determine the associated drawdown, usually by the extrapolation method. Thereafter it is necessary to calculate the recovery data $\left(s^{\prime \prime}\right)$ as the distance between the water level at the time $\left(t^{\prime}\right)$ after stop of pumping, and the respective drawdown at 
the time $(t)$ after start of pumping. Over a long period this is impractical and therefore the following method is proposed:

If the plot $(s)$ on the linear scale and $(t)$ on the logarithmic scale is used, if boundaries are not present, and if the discharge is maintained constant the drawdown, at any time after stop of pumping, can be calculated by means of the formula:

$$
s=\Delta s \times \log \left(t / t_{0}\right)
$$

If equilibrium in the aquifer is reached during the pumping period, this procedure is not valid.

If hydrologic boundaries appear within the cone of depression during the pumping period, then the slope of the drawdown data, due to boundary influence and its intersection on the $s=0$ axis, may be used for the computations of the drawdown at the required time $(t)$ after start of pumping.

\section{CORRECTIONS FOR BAROMETRIC EFFICIENCY}

\section{THEORY}

It is well known that water levels in wells tapping an artesian aquifers fluctuate with changes in atmospheric pressure.

The size of the reaction during atmospheric pressure fluctuations is called "barometric efficiency of the artesian aquifer" and is usually expressed in per cent. The barometric efficiency for an aquifer should be calculated in periods where there is no fluctuations of the water level, due to the pumping or any artificial change in the piezometric head. The following formula is used for the computation of the barometric efficiency:

$$
B E=\frac{\Delta W}{\Delta \mathrm{P} \times 1,36} 100, \text { per cent }
$$

When the value of $B E$ is known, changes of the water level in the well during the pumping test, due to changes of the atmospheric pressure, can be calculated by using the formula:

$$
\Delta W=\frac{B E \times \Delta P \times 1,36}{100}, \mathrm{~cm}
$$

All atmospheric pressure changes observed during the pumping test must be referred to one arbitrarily chosen point of references. Usually the value of the atmospheric pressure before start of pumping is taken as the referent value. According to the relative change in the atmospheric pressure, calculated values of the water level changes will be added or subtracted from the measured water level during the drawdown period. The magnitude of the change in the water level will depend on the amount of the fluctuation in the atmospheric 
pressure and the value of $B E$. During the recovery period, it is possible to correct either the residual drawdown or recovery data.

\section{CORRECTION OF RESIDUAL DRAWDOWN ( $\mathrm{s}^{\prime}$ )}

As previously mentioned the formula for residual drawdown is:

$$
s^{\prime}=\left(s-s^{\prime \prime}\right)=s-\left(s-s^{\prime}\right)
$$

By applying the corrections for the changes in the atmospheric pressure follows:

$$
s^{\prime}=(s \pm \Delta W)-\left[(s \pm \Delta W)-\left(s^{\prime} \pm \Delta W^{\prime}\right)\right]
$$

and finally

$$
s^{\prime}=\left(s^{\prime} \pm \Delta W^{\prime}\right), \mathrm{m} \text {. }
$$

Therefore it is necessary to measure the distance between the static level prior to the test and the water level at the time $t^{\prime}$ after stop of pumping. The calculated values of $\Delta W^{\prime}$, depending on the direction of the relative change in the atmospheric pressure $\Delta P^{\prime}$ after stop of pumping, should then be added to or subtracted from the residual drawdown data.

The following formulas can then be applied:

Decrease of air pressure $\left(-\Delta P^{\prime}\right)$ 1. $s^{\prime}=\left(s^{\prime}+\Delta W^{\prime}\right), \mathrm{m}$.

Increase of air pressure $\left(+\Delta P^{\prime}\right) \quad 2 . \quad s^{\prime}=\left(s^{\prime}-\Delta W^{\prime}\right), \mathrm{m}$.

For example, from Table 1 residual drawdown $s^{\prime}$ at $t^{\prime}=300$ minutes:

$$
s^{\prime}=0,088 \mathrm{~m} \text {. }
$$

The relative change in the atmospheric pressure from $t^{\prime}=0$ to $t^{\prime}=300 \mathrm{mi}-$ nutes is:

$$
-\Delta P^{\prime}=1,6 \mathrm{~mm}
$$

Applying $B E=30$ per cent and formula (15)

$$
\Delta W^{\prime}=0,007 \mathrm{~m} \text {. }
$$

Then by means of the formula (16a):

$$
s^{\prime}=0,088+0,007=0,095 \mathrm{~m} .
$$

3. CORRECTION OF RECOVERY ( $\left.\mathrm{s}^{\prime \prime}\right)$

As previously mentioned the formula for recovery is:

$$
s^{\prime \prime}=\left(s-s^{\prime}\right), \mathrm{m} \text {. }
$$

By applying the corrections for the changes in the atmospheric pressure it follows:

$$
s^{\prime \prime}=(s \pm \Delta W)-\left(s^{\prime} \pm \Delta W^{\prime}\right)
$$

There are two ways to obtain corrected $s^{\prime \prime}$, depending on how $s$ and $s^{\prime}$ are recorded. 
If data of $s$ are already corrected then $s^{\prime}$ can be corrected, applying one of the formulas for respective $\Delta P^{\prime}$, after stop of pumping.

From Table 1, for example, $s$ at the end of the pumping test was

and

$s=1,045 \mathrm{~m}$ (corrected value for $\triangle P$ and $B E=30$ per cent)

was

$$
\begin{aligned}
& s^{\prime} \text { at } t^{\prime}=300 \mathrm{~min} . \\
& s^{\prime}=0,088 \mathrm{~m}
\end{aligned}
$$

$\Delta P$ from $t^{\prime}=0$ to $t^{\prime}=300 \mathrm{~min}$. was

$-\Delta P^{\prime}=1,6 \mathrm{~mm}$.

By applying $B E=30$ per cent and formula (15)

$$
\Delta W^{\prime}=0,007 \mathrm{~m}
$$

and by means of formulas (16a) and (17)

$$
\begin{array}{ll} 
& s^{\prime}=0,088+0,007=0,095 \mathrm{~m} \\
\text { then finally } & s^{\prime \prime}=1,045-0,095=0,950 \mathrm{~m}
\end{array}
$$

If data of $s$ and $s^{\prime}$ are taken from the graph where water level during the pumping test is recorded, then neither values are corrected for the atmospheric pressure changes during the pumping test.

In this case the resulting value of $\Delta W$ and $\Delta W^{\prime}$, for respective $\Delta P$ during drawdown and recovery period, should be added or subtracted from the difference of $s-s^{\prime}$, as follows:

$$
\begin{aligned}
& \text { Drawdown period: }-\Delta P=+\Delta W \\
& +\Delta P=-\Delta W \\
& \text { Recovery period: } \quad-\Delta P^{\prime}=-\Delta W^{\prime} \\
& +\Delta P^{\prime}=+\Delta W^{\prime}
\end{aligned}
$$

From Table 1, for example, $s$ at the end of pumping was

$$
s=1,025 \mathrm{~m}
$$

and the change in the atmospheric pressure after start of pumping was

$$
-\Delta P=4,8 \mathrm{~mm} \text {. }
$$

By applying $B E=30$ per cent and formula (15)

$$
\Delta W=0,020 \mathrm{~m} \text {. }
$$

The value of the residual drawdown $\left(s^{\prime}\right)$ at $t^{\prime}=300 \mathrm{~min}$. was

$$
s^{\prime}=0,088 \mathrm{~m} \text {. }
$$

Subsequently the pressure change was

$$
-\Delta P^{\prime}=1,6 \mathrm{~mm},
$$


and then the change of water level

$$
\Delta W^{\prime}=0,007 \mathrm{~m} \text {. }
$$

Finally by applying the formulas (17), (18a) and (19a)

then finally

$$
\begin{aligned}
& s^{\prime \prime}=1,025-0,088=0,937 \mathrm{~m} \\
& +\Delta W-\Delta W^{\prime}=+0,02-0,007=+0,013 \mathrm{~m} \\
& s^{\prime \prime}=0,937+0,013=0,950 \mathrm{~m} .
\end{aligned}
$$

\section{COMPARISON OF RESULTS}

In Table 2 are given coefficients of transmissivity and storage, calculated from the drawdown data and the different terms of the recovery data, based on different graphical methods.

From this table it can be seen, that $T$ values calculated from the drawdown data, and the data from the different terms of recovery are almost similar.

By comparing $T$ values from the drawdown data with $T$ values from the recovery data $\left(s^{\prime \prime}\right)$, calculated by means of the Theis type curve method, it

\begin{tabular}{|c|c|c|c|c|c|}
\hline & \multicolumn{2}{|c|}{ Drawdown data } & \multicolumn{3}{|c|}{ Recovery data } \\
\hline & semilog plot & $\log -\log$ plot & semilog plot & linear plot & log-log plot \\
\hline $\mathrm{T} \times 10^{-2} \mathrm{~m}^{2} / \mathrm{sec}$. & 1,71 & 1,20 & $\begin{array}{l}1,62^{\prime} \\
1,74^{\prime \prime}\end{array}$ & $\begin{array}{l}1,59^{\prime} \\
1,12^{\prime}\end{array}$ & $1,24^{\prime \prime}$ \\
\hline $\begin{array}{l}\mathrm{S} \times 10^{-5} \ldots \ldots \ldots \\
\mathrm{S}^{\prime} \times 10^{-5}\end{array}$ & 4,525 & 16,30 & $\begin{array}{l}0,89^{\prime} \\
3,65^{\prime} \\
3,68^{\prime}\end{array}$ & $\begin{array}{l}0,86^{\prime} \\
\mathrm{S}=\mathrm{S}^{\prime}\end{array}$ & $15,70^{\prime \prime}$ \\
\hline
\end{tabular}
can be seen, that they are almost similar.

Table 2. Coefficients of $T$ and $S$ from drawdown and different terms of recovery data.

(') residual drawdown $=\left(\mathrm{s}^{\prime}\right)$

(") recovery $=\left(\mathrm{s}^{\prime \prime}\right)$

By comparing $T$ values calculated by means of the Jacob's method from the drawdown data with the values computed from the different terms of the recovery it can be seen, that there are practically no differences. Nevertheless, when recovery data $\left(s^{\prime \prime}\right)$ are used, the comparison of $T$ values based on drawdown and recovery data are in even closer agreement. By means of the correction factor suggested by WeNZEL, $T$ value appears too small, although it is 
close to the values calculated by Theis type curve method. However, as stated by ЈАСОВ (1963), "the transmissivity should be determined from the slope of the curve through the uncorrected data of the residual drawdown $\left(s^{\prime}\right)$ ". From the data and their analysis presented here it can be concluded, that it is more practical to use the recovery data $\left(s^{\prime \prime}\right)$ instead of the residual drawdown $\left(s^{\prime}\right)$, for the determination of the transmissivity, though there is no great difference between the two sets of results.

Regarding the storage coefficient there are great differences between values calculated from the different terms of recovery data, $\left(s^{\prime}\right)$ and $\left(s^{\prime \prime}\right)$, and the drawdown data $(s)$. When the ratio $S / S^{\prime}$ on the intersection $\left(t / t^{\prime}\right)_{0}$ from the residual drawdown $\left(s^{\prime}\right)$ is determined, the relative change between the $S$ from the drawdown period and $S^{\prime}$ from the recovery period is 80 per cent, which is unlikely. By means of Wenzel correction factor the straight line through plotted $s^{\prime}$ data would pass through the origin equalising on this way $S$ with $S^{\prime}$. However this is an artificial procedure, which tells nothing about the change in the storage coefficient after stop of pumping. Moreover it provides a $T$ value, which is too small. When $S^{\prime}$ values are calculated from the recovery data $\left(s^{\prime \prime}\right)$ the relative change of $S^{\prime}$ in comparison with $S$-computed by means of the Theis or the modified non-equilibrium formulas - is 3,6 per cent for logarithmic plot, and 19 per cent for semilogarithmic plot, which is possible. However, $S^{\prime}$ values from semilog plot of $s^{\prime \prime}$ compared with $S^{\prime}$ from logarithmic plot of $s^{\prime \prime}$ are 77 per cent smaller. The same relation exists between $S$ values found from the drawdown data. This suggests that the data should be analysed by both methods. Here it should be mentioned that the artesian aquifer, from which the data is obtained, is a leaky artesian aquifer which is now in investigation for development. The aquifer distribution and the hydraulic properties are well-known from several well logs and pumping tests, respectively.

\section{CONCLUSIONS}

From analysis of the different ways of measuring recovery data after stop of pumping, it is possible to conclude the following: Recovery data $\left(s^{\prime \prime}\right)$-measured as the difference between the water level at the time $(t)$ after start of pumping and the water level at the time ( $\left.t^{\prime}\right)$ after stop of pumping, both referred to the static level prior to the test - can be advantagously used for the determination of the $T$ and $S^{\prime}$ coefficients from the recovery period of the pumping test. When $T$ and $S^{\prime}$ values are calculated from the recovery data $\left(s^{\prime \prime}\right)$ they will give good results in comparison with $T$ and $S$ value from the drawdown data. On the other hand, the residual drawdown $\left(s^{\prime}\right)$ - measured as the distance between the static level prior to the test and the water level at the time $\left(t^{\prime}\right)$ after stop of pumping - will not give the proper $S^{\prime}$ values. However, $T$ values calculated from the residual drawdown $\left(s^{\prime}\right)$ can be used in further calculations.

Furthermore the drawdown data, which would appear if pumping continued, 
can be calculated in a simple way by the formula: $s=\Delta s \times \log \left(t / t_{0}\right)$. Thereafter the drawdown is used to calculate recovery $\left(s^{\prime \prime}\right)$.

If the water levels are under the influence of atmospheric pressure, the correction procedure as given should be applied.

\section{ACKNOWLEDGEMENT}

Thanks are due to Dr. I. Mucha for the valuable discussions and reading of this paper.

\section{DANSK SAMMENDRAG}

Hydrogeologisk Afdeling ved Danmarks Geologiske Undersøgelse har i de senere år udført prøvepumpningsforsøg med henblik på bestemmelsen af de hydrauliske egenskaber i et grundvandsreservoir.

Til dette formål anvendes almindeligvis data for sænkningen af vandstanden i forbindelse med en prøvepumpning. Data for vandstandsstigningen efter pumpningens ophør vil imidlertid også kunne benyttes til dette formål, og i visse tilfælde endog med et bedre resultat, idet mindre uregelmæssigheder i pumpekapaciteten ikke vil influere på stigningshastigheden efter pumpningens ophør i samme grad som på sænkningshastigheden i pumpeperioden.

De forskellige måder, hvorpå vandstandsstigningen efter pumpningens ophør kan angives, fremgår af Fig. 1.

Residualsænkningen $\left(s^{\prime}\right)$ er lig med afstanden mellem ro-vandstanden, for pumpningen påbegyndes, og vandstanden ved tiden $\left(t^{\prime}\right)$ efter pumpningens ophør, (den ikke retablerede del af sænkningen). Stigningen $\left(s^{\prime \prime}\right)$, (den retablerede del af sænkningen) angives som forskellen mellem vandstanden ved slutningen af pumpeperioden og vandstanden ved tiden $\left(t^{\prime}\right)$ efter pumpningens ophør. Denne stigning $\left(s^{\prime \prime}\right)$ kan dog også angives som forskellen mellem vandstanden ved tiden $\left(t^{\prime}\right)$ efter pumpningens ophør og det niveau, den afsænkede vandstand ville indtage, hvis pumpningen havde fortsat i tiden $\left(t^{\prime}\right)$ efter pumpningens ophør. Denne sænkning, som er nødvendig for beregningen af stigningen $\left(s^{\prime \prime}\right)$ under ikke stationære forhold, kan bestemmes ved hjælp af formel (13).

På basis af data fra en prøvepumpning på en boring ved Hvinningdal vest for Silkeborg, DGU ark. nr. 87.551, er værdier for transmissivitetskoefficienten $T$ og magasinkoefficienten $S$ ( $S^{\prime}$ for stigningsdata) beregnet på basis af såvel sænkningshastigheden under pumpning som stigningshastigheden efter pumpningens ophør.

Da grundvandstanden i artesiske grundvandsforekomster oftest er påvirket af ændringer i lufttrykket, er det nødvendigt at korrigere alle observationer for den såkaldte barometereffekt $(B E)$. Formler for korrektion for barometereffekten samt eksempler fra Tabel 1 er gennemgået. 
På basis af de udførte beregninger og sammenligninger af værdierne for de hydrauliske egenskaber $T$ og $S\left(S^{\prime}\right)$ for det undersøgte grundvandsreservoir beregnet for sænknings- og stigningsdata kan konkluderes, at stigningen $\left(s^{\prime \prime}\right)$ med fordel kan benyttes ved bestemmelsen af de hydrauliske egenskaber for et grundvandsreservoir. Der er god overensstemmelse mellem $T$ - og $S$-værdier bestemt på basis af sænkningsdata og stigningsdata (se Tabel 2). Derimod vil residualsænkningen $\left(s^{\prime}\right)$ ikke give korrekte værdier for magasinkoefficienten $\left(S^{\prime}\right)$, mens værdier for transmissivitetskoefficienten $(T)$ kan bestemmes tilstrækkeligt korrekt ud fra residualsænkningen.

\section{LITERATURE}

Davis, N. S., De Wiest, G. R., 1966: Hydrogeology, pp. 222-223. John Wiley and Sons, New York.

FERRIS, G. J. and all., 1962: Theory of aquifer tests pp. 100-102. Geological Survey Water-Supply Paper 1536-E.

J АСOB, E. C., 1941: Coefficients of storage and transmissibility obtained from pumping tests in the Houston District, Texas. Trans. Am. Geoph. Union Part III, pp. 744-756.

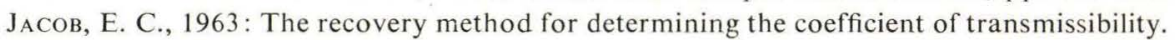
Methods of determining permeability, transmissibility and drawdown. Geological Survey Water-Supply Paper 1536-I, pp. 283-292.

Lohman, W. S., 1963: Methods for determination of the coefficient of storage from straight-line plots without extrapolation. Shortcuts and special problems in aquifer tests, pp. 33-37. Geological Survey Water-Supply Paper 1545-C.

Theis, C. V., 1935: The relation between the lowering of the piezometric surface and the duration of discharge of a well using ground water storage. Trans. Am. Geoph. Union, vol. 16, pp. 519-524.

ToDD, K. D., 1959: Ground Water Hydrology, pp. 97-98. John Wiley and Sons, New York.

WENZEL, L. K., 1942: Methods for determining permeability of water bearing material, pp. $94-97,125-127,141$. Geological Survey Water-Supply Paper 887. 
ISBN 8742106044 ANDELSBOGTRYKKE RIET । ODENBE 